\title{
Determinants of Weaknesses in Internal Control of Provincial Government in Indonesia
}

\author{
Rizal Yaya* and Halim Sri Suprobo
}

\begin{abstract}
This study aims at examining and analysing factors that cause weaknesses in internal control system of provincial local government. Population of this study is all 34 provincial governments in Indonesia and the studied object is internal control weaknesses identified in the Provincial Government Audit Reports produced by the Audit Board of the Republic of Indonesia. Eighty three reports were used as sample ranging from 2011 to 2015. The research model of this study indicates adjusted R2 at $86 \%$ which is much higher than previous studies on this topic, Based on the multiple regression analysis, it is found that the size of local government and the use of information technology have a significant negative effect on the weaknesses of internal control. This implies that Provincial Government needs to use more information technology and allocate more resources on internal control improvement. On the other hand, the complexity of local government and the quality of human resources have positive effect on the weaknesses of internal control. These findings suggest provincial governments with large number of sub-districts to put more efforts in internal control system improvement than others. The provincial government with higher human development index needs more efforts on ethical conduct. This study contributes in investigating both financial and non-financial factors affecting internal control weaknesses of provincial government for longer period of analysis.
\end{abstract}

Keywords: Internal Control Weaknesses; Local Government Size; Local Government Complexity; Human Development Index; Technological Use

\section{ARTICLE HISTORY}

\section{Received:}

12 July 2019

\section{Reviewed:}

4 August 2019

Revised:

12 August 2019

\section{Accepted:}

7 September 2019

\section{Introduction}

Organisation such as local government needs internal control to perform their duties to provide services to the community. This includes in all aspects of governance such as budget implementation, safeguarding resources, accounting and reporting. It is needed because the internal control that run well will have implications on the creation of good governance (Asare, 2009). Benedek, Szenténé, and Béres (2014) added that those services can improve society's welfare and prosperity.

In Indonesia, internal control practice for Government institution is regulated by the Government Regulation No. 60 year 2008. The 
regulation is the follow-up of Article 58, Act No. 2 year 2004 on Government Treasury, which requires the government to have detail regulation on Government internal control. In that article, it is stated to improve the performance, transparency, and accountability of government financial management, the President as the Head of Government should perform and organize internal control system comprehensively for the whole government organization. This regulation is in line with studies on the importance of internal control in public sector. Asare (2009) explained that a good internal control can contribute to the good governance and accountability process through their assessment on the effectiveness of key organisational, controls and risk management process. He added that the development of internal audit practice has put that profession as partner to governance bodies with strategic focus on the improvement of organisational governance. This view is supported by empirical studies in developed country like United States. A study by Rich and Zhang (2014) on the effectiveness of internal audit in municipals in the United States, found that municipalities with audit committee tend to have fewer internal control problems and also has less likely to experience with significant financial reporting failures.

Audit Board of the Republic of Indonesia namely as Badan Pemeriksa Keuangan (BPK) has regularly examined and supervised government internal control system. The objective of the examination is to assess the effectiveness of an entity's internal control three areas: accounting and reporting control, budget implementation control and internal control structure. The examination is based on the assessment of the internal control weaknesses in accounting and reporting; weaknesses in controlling budget implementation; and weaknesses in internal control structure. Based on their reports, the internal control weaknesses of local government in Indonesia have steadily increased from year 2011 to 2015 (Badan Pemeriksa Keuangan, 2016).

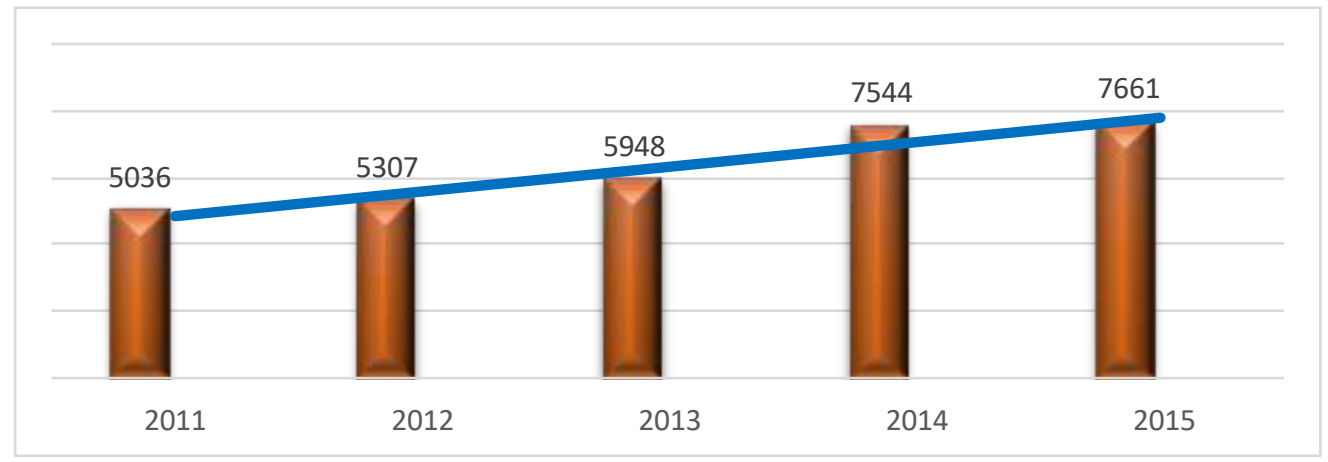

Figure 1 Number of Audit Board's Findings on Internal Control Weaknesses of Indonesian Local Governments

Source: Badan Pemeriksa Keuangan (2012-2016)

Figure 1 shows that the number of problems found in internal control weaknesses increases every year. If it is compared 5036 findings in the year 2011, the findings of internal control weaknesses increased $50 \%$ within five years period. This condition indicates greater challenges faced by civil servants in implementing effective internal 
Yaya \& Suprobo

Determinants of Weaknesses in Internal Control of Provincial Government in Indonesia

control system. For 2015 , it was reported 10,198 cases with 15,568 findings comprising $7,661(49 \%)$ on internal control weakness and 7,907 (51\%) non-compliance with regulation.

This situation shows that it is not enough for just having the Audit Board in place to supervise Government internal control. Therefore, there is a need to find out factors which can ensure an effective internal control system. Previous studies undertaken by Kristanto (2009), Nurwati and Trisnawati (2015), Putri and Mahmud (2015) and Yamin and Sutaryo (2015) have investigated factors, such as size of local government, complexity of local government, total expenditure and total revenue of local government as determinants of internal control weaknesses. However, these studies had limitations in terms of independent variables and period of analysis. To improve the research model, this study uses combination of financial and non-financial independent variables. The use of non-financial variables is suggested by Doyle, Ge, and McVay (2007) when they investigate profit-oriented organisations after Sarbanes Oxley regulation. The financial variable is size or total asset of the local government, while the non-financial variables are economic growth, local government complexities, quality of human resources and the use of information technology. In addition, this study extends the period of analysis from one year into five years data analysis. By investigating both financial and non-financial variables and longer period of analysis, this study contributes to wider scope of research variable and greater validity of generalisation for Indonesian provincial government.

The purpose of this study is to identify factors that influence weaknesses in internal control of provincial governments in Indonesia. The increases weaknesses found in internal control examination needs further investigation on factors affecting them. This study investigates not only the financial variable but also non-financial variables as determinants of the increase weaknesses. A finding of this study is expected to be able to contribute in assisting Central Government as regulator and local governments as executor in identifying the most influential determinants on the internal control weaknesses of Indonesian local government.

\section{Literature Review and Hypotheses Development}

\section{Internal Control System}

The Committee of Sponsoring Organisation of The Treadway Commission (COSO) defines that "Internal control is a process, effected by an entity's directors, management, and other personnel, designed to provide reasonable assurance regarding the achievement of objectives relating to operations, reporting, and compliance" (COSO, 2013). This definition has been adopted in the Government Regulation (PP) no 60 year 2008 that internal control is an integrated process on actions and activities which are continuously performed by top management and all employees to give reasonable assurance in achieving organisation goals through effective and efficient activities, reliable financial report, protecting government asset, and compliance with regulation. Government 
Internal Control System (GICS) is an internal control system performed in the whole area of central and local government. In its implementation, it should incorporate fairness, and appropriateness principle considering size, complexity, and nature of task and function of the government institution.

Based on the Government Regulation no 60 year 2008, Government Internal Control System comprises:

\section{Control Environment}

Top management and all employees of government institution should create and enhance the environment in all area of organisation which leads to positive behaviour and support for health management and internal control.

a. Risk Assessment

Internal control should make an assessment on risk faced by the organisation both from internal and external. Risk assessment starts with setting up organisational objectives and goals which are consistent at institution level and activity level. Then, the Government institution identifies risks that can obstruct goals achievement whether from internal or external of the institution. The top management of the government institution should formulate appropriate risk management approach and risk control activities to reduce the risk.

b. Risk Control

Risk control helps to ensure top management policy has been implemented. In this regard, control activities should be efficient and effective in achieving organisation goals.

c. Information and Communication

Information should be recorded and reported to the head of Government Agencies and other parties specified. Government agencies should have both financial and non-financial information relating to external and internal events. Such information shall be communicated in a form and within the time frame, enabling the concerned to exercise internal control and operational responsibilities.

d. Monitoring of Internal Control

Monitoring should be able to assess the quality of performance over time and ensure that recommendations of audit results from other reviews can be followed up immediately. Ongoing monitoring is conducted through routine management, supervision, benchmarking, reconciliation and other related actions in the performance of the task. Separate evaluations are conducted through selfassessment, review and testing of the effectiveness of the Internal Control System that can be carried out by government internal oversight apparatus or external government parties. 
Yaya \& Suprobo

Determinants of Weaknesses in Internal Control of Provincial Government in Indonesia

\section{Stewardship Theory}

Studies on the internal control system can be analysed based on stewardship theory and accountability theory. Donaldson and Davis (1991) explained that Stewardship theory is based on the assumption that managers' motives are aligned with the objectives of their principals. Managers are not motivated by individual goals but rather are stewards. Thus, under this theory, managers will behave and act according the common goal. This is applicable to the local government situation. According to this theory, government apparatus will behave and work according to the common interests referring to society's interest.

Under stewardship theory, in the situation of conflict of interest between steward and principal, the steward will strive to work together rather than against the principal. The logic consideration to this is that to achieve common goals by behaving according to the principal's expectation. Stewardship theory explains a strong relationship between organisation success with the owner's satisfaction. Therefore, the government will do its obligation to fulfil the interest of the people. Whenever their's interests have been met, people as the owner will satisfy with the performance of the government. The successful government performance indicates that internal control within the Government Agencies has run well and the organisation objectives have been achieved optimally.

\section{Accountability Theory}

Accountability is the concept which has a broader scope than stewardship. Stewardship refers to managing activity to serve the principal without any obligation to report it. Meanwhile, accountability refers to the steward's accountability to the party who gave authority (Mardiasmo, 2002). Thus, accountability is the form to be accountable for one party to the other party. Frink and Klimoski (2004) said that Accountability involves an actor or agent in a social context who is potentially subject to observation and evaluation by some audience(s). Based on the accountability theory, an organisation is given the obligation to provide accountability regarding the control of resources used by the organisation. The existence of good controls allows the organisation to provide better accountability and is relevant to the actual situation. When the internal control of an organisation goes well, then the accountability that will be provided by the organisation will also be better than the organisation that has weak internal control.

\section{Hypotheses Development}

Putri and Mahmud (2015) found that government size has a negative effect on the internal control weaknesses, indicating that the higher government size the lower internal control weaknesses. This is different from Kristanto (2009) who found that local government size has positive effect on internal control weakness of local government, meaning that local government with high asset tends to have high internal control weaknesses. Based on accountability theory, local government with bigger size indicates to have more source of resources which will drive them to be more accountable. The size of government determines the quality of internal control. The bigger the size of a govern- 
ment the more complex the problem will be. Therefore, if the size of the government gets bigger, without any development, the internal control of the local government will be weakened. In contrast, local government internal control will be effective if the size of the government is small as the problem is relatively fewer. Based on this argument, it can be formulated hypothesis 1 as follows:

$\boldsymbol{H}_{1}$ : The size of the local government has a positive effect on the weaknesses of local government's internal control.

The result of Putri and Mahmud (2015) shows that the economic growth of local government has no effect on internal financing of local government. However, Mahmud and Utaminingsih (2014) found that economic growth negatively affects the weaknesses of local government internal controls. Economic growth means that local government would have more potential resources to account for. It is expected that local government in the area with higher economic growth will be driven to better accountability through reducing the number of internal control weaknesses. Rapid economic growth also indicates a well-run local government internal control. Increasing economic growth will lead to improved implementation of internal controls as well. Because the better the internal control level will result in more rapid economic growth of a region. Therefore, hypothesis 2 is formulated as follows:

$\boldsymbol{H}_{2}$ : Economic growth negatively affects the weaknesses of local government internal controls.

Previous research conducted by Saputro and Mahmud (2015) found that the increase and decrease in local government complexity measured by using the number of districts within the local government will not affect the occurrence of cases of internal control weaknesses. In contrast to the results of research studies by Doyle et al. (2007) in private sector, they found that the complexity measured using figures from entityspecific reporting statements, segment reports, and foreign currency translations has an influence on the weaknesses of internal control. The more complex the local government the more complicated internal control that must be managed. As local governments become more complex, there will be difficulties in monitoring and managing them. Therefore, the increased complexity of local government will result in increased weaknesses of their internal control. Based on the discussion it can be formulated hypothesis as follows:

$\boldsymbol{H}_{3}$ : Local government complexities have a positive effect on the weaknesses of local government internal control.

Nafidah (2011) conducted research on the influence of human resource quality on internal control system by using indicators of education, experience, and training. The 
study found that education and training have a significant influence on internal control system, while experience has no influence on the internal control system.

The link between the quality of human resources and internal control is quite close. Human resources are responsible for carrying out basic tasks and functions of an organisation. Based on stewardship theory, the area with high human development index has chance to have better quality and competency of human resources. This, in turn, is expected to have better internal control. This control will be effective when the capacity and capability of human resources are met. However, when the available human resources are inadequate or incompetent, there will be weaknesses of internal control. According to this argument, the following hypothesis is formulated as follows:

$\boldsymbol{H}_{4}$ : The quality of human resources negatively affects the weaknesses of local government internal control.

Yamin and Sutaryo (2015) suggest that the use of ICTs as measured by e-Government ratings does not affect the weaknesses of internal control. However, Ardi (2013) found that the utilisation of reliable information technology will create effective internal control. This is because the progress and utilisation of information technology affect the development of accounting information system in terms of data processing, internal control of the organisation and increasing the number and quality of information in financial reporting. From the perspective of accountability theory, the existence of technology information supports local government to perform their accountability through reduction of internal control weakness. Therefore, when organisations use more information technology, the weakness of control that will be encountered in the organisation will be less. Based on this argument, it can be formulated hypothesis as follows:

$\boldsymbol{H}_{5}:$ The use of information technology has a negative effect on the weakness of local government's internal control.

\section{Research Method}

\section{Sample}

Population of this research is all Provincial Government in Indonesia. The object of the study is internal control weaknesses identified in the Provincial Government Audit Reports produced by the Audit Board of the Republic of Indonesia. The sample in this study is 83 reports audit reports produced by the Audit Board of the Republic of Indonesia ranging from 2012 to 2016 for the Budget year between 2011 to 2015. The process of data selection is based on as follows. Table 1 shows the criteria in Selecting Research Sample. 
Table 1 Criteria in Selecting Research Sample

\begin{tabular}{clc}
\hline No & \multicolumn{1}{c}{ Criteria } & Total \\
\hline 1 & Total number of available Provincial Government audit report 2011- 2015 & 168 \\
2 & Number of research object with negative economic growth & $(5)$ \\
3 & Number of research object without e-Government ranking & $(58)$ \\
4 & Outlier & $(22)$ \\
5 & Research object with complete data & 83 \\
Total sample for five years observation based on purposive sampling method of selection & 83 \\
\hline
\end{tabular}

\section{Types of Data}

Data used for all investigated variables are secondary data. These data were obtained from the website of the Audit Board of the Republic of Indonesia, Statistics Bureau and the Ministry of Information and Communication. The Audit Report of Semester Examination Result Report (IHPS) published by the Audit Board was obtained from the Audit Board website (www.bpk.go.id). Data on the rate of GDP, the number of districts and HDI were obtained from the Statistical Bureau website (www.bps.go.id). Finally, data on the use of information technology were obtained from the website of the Ministry of Information and Communication (www.pegi.layanan.go.id). Table 2 shows the measurement of research variables.

Table 2 Measurement of The Variables

\begin{tabular}{ll}
\hline Variables & Measurement \\
\hline Internal Control Weakness & $\begin{array}{l}\text { Number of cases of internal control weaknesses and reports + } \\
\text { Number of cases of internal control weakness in the implemen- } \\
\text { tation of revenue and expenditure budget + Number of cases of } \\
\text { weaknesses in control structure. }\end{array}$ \\
\hline $\begin{array}{l}\text { Sotal Asset } \\
\text { Economic Growth }\end{array}$ & $\begin{array}{l}\text { Economic growth of province } \\
\text { Number of districts } \\
\text { Human resource quality } \\
\text { The use of information } \\
\text { technology }\end{array}$ \\
\hline
\end{tabular}

\section{Data Analysis}

This research used multiple regression statistical analysis of SPSS version 22. The equation of the multiple regressions is as follows:

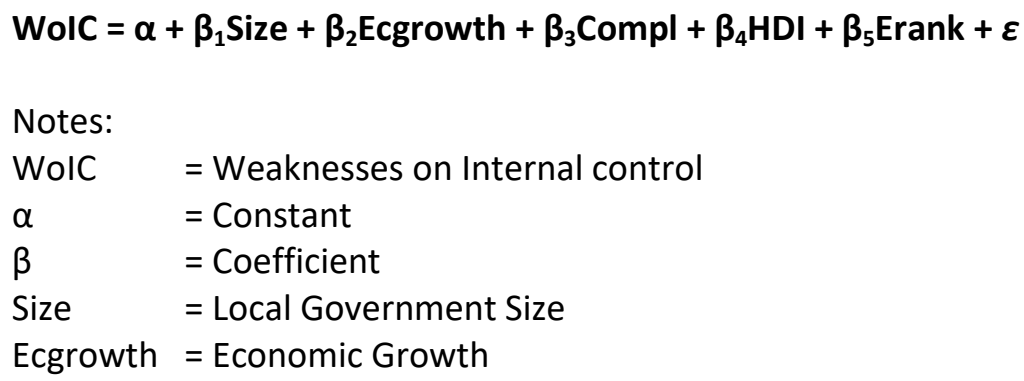




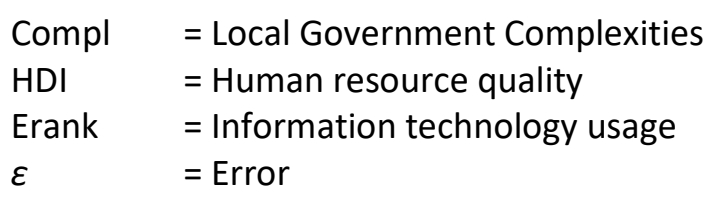

\section{Result and Discussion}

\section{Testing the Assumption of Linear Regression}

The result of the normality test in this study is based on the Kolmogorov-Smirnov OneSample test. The test result shows that the K-S value is 0.200 with a significance value above 0.05 . This indicates that the residual value is normally distributed or meets the classical assumption. The result of the autocorrelation test shows that the Durbin Watson (DW) value is 1.802 with the total unit of analysis (n) is 83 and the number of independent variables $(\mathrm{k})$ is 5 so that the $\mathrm{dU}$ value is 1.7728 and the $\mathrm{dL}$ value is 1.5183 . Therefore, as $1.7728<1.802<2.4817$ or $\mathrm{dU}<\mathrm{dW}<(4-\mathrm{dL})$, it can be concluded that the data in this study are free from autocorrelation problems. Multicollinearity test results show VIF $<10$ and Tolerance $>0.10$ from each variable. This indicates that there is no multicollinearity in the variables studied. Finally, in terms of heteroscedasticity, data can be concluded to be free from heteroscedasticity problem if it has a significant value greater than 0,05 . The result of heteroscedasticity test of this data show significance value greater than 0,05 . This indicates the data of this study is free from the heteroscedasticity problem.

\section{Descriptive Statistics}

Statistics descriptive shows data about minimum, maximum, mean and standard deviation of variables investigated (Table 3). Independent variable of weaknesses of internal control varies from 20 to 372 weaknesses. Mean data of 139 indicates that there is still a high number of internal control weaknesses.

Table 3 Descriptive Statistics

\begin{tabular}{lrrrrr}
\hline Variabel & $N$ & Minimum & Maximum & Mean & Std. Deviation \\
\hline WolC & 83 & 20 & 372 & 139.40 & 77.159 \\
Size & 83 & $962,165,353,684$ & $425,353,600,919,700$ & $33,394,133,283,316$ & $94,655,187,934,706$ \\
Ecgrowth & 83 & 0.00 & 0.21 & 0.0623 & 0.02508 \\
Complexity & 83 & 44 & 664 & 200.20 & 175.443 \\
HDI & 83 & 55.55 & 78.99 & 67.5747 & 4.91630 \\
e-rank & 83 & 1.2 & 3.39 & 2.2837 & 0.56013 \\
\hline
\end{tabular}

\section{Regression Testing Results}

Table 4 shows the Regression Test Result. It can be seen that the result of determination coefficient test shows that the value of Adjusted R2 is 0,860 . This figure indicates that $86.0 \%$ of the variation of the dependent variable (weakness of internal control) can be explained by the variation of independent variables in this study (Total Assets, Economic Growth, complexity, HDI and the use of information technology). 
The result of simultaneous test ( $F$ statistic test) shows significance at 0.000 . This means a level of significance of $<5 \%(\alpha=0.05)$ which means the hypothesis is accepted. It can be concluded that the size of local government, economic growth, local government complexity, the quality of human resources and the utilisation of information technology simultaneously have a significant effect on the weaknesses of internal control.

Table 4 Regression Test Result

\begin{tabular}{lll}
\hline Variables & B Value & Sig. Value \\
\hline Total Asset & $-1.357 \mathrm{E}-13$ & .001 \\
GDP & 60.444 & .646 \\
Complexity & .429 & .000 \\
\hline HDI & 3.872 & .000 \\
\hline e-rank & -14.719 & .044 \\
F-test & & 0.000 \\
Adj R Square & & .860 \\
\hline
\end{tabular}

The $t$-test result for hypothesis one has significance value equals to 0.001 and negative coefficient direction of -1.357 . This can be concluded that if there is an increase in the size of local government it will decrease the number of cases of weaknesses of internal control. This hypothesis is rejected because of having negative direction. The results of this study are not in line with research Kristanto (2009) who found that the size of local governments has a positive influence on the weaknesses of local government internal control. However, this finding is in line with Putri and Mahmud (2015) meaning that the larger the size of local government, the weakness of internal control will be smaller. This indicates that local government with higher asset has been able to use the asset to improve internal control. This also supports stewardship theory that government as an agent will use resources that the government has to meet people's expectation to have good government practice.

T-test result for hypothesis two has a significance value of 0.646 and positive coefficient direction equal to 60.444 . As it has significance value above 0.05 , hypothesis two is rejected. The result of this study is not in line with research of Hartono, Mahmud, and Utaminingsih (2014). However, it is in line with the research of Putri and Mahmud (2015) indicating that high economic growth does not necessarily guarantee its internal control is also better than local governments that have lower economic growth. Thus, economic growth in local government can not be used as an indicator of the causes of weaknesses of local government's internal control system.

The test results for hypothesis three has a significance value below $5 \%(\alpha=0.05)$ that is equal to 0.000 and have direction of positive coefficient. That is, if there is an increase in the number of districts by 1 , will have an impact on the increase in internal control weakness of 0.429 cases. The conclusion of these results is that hypothesis three is accepted because the test results show a positive and significant direction. In conclusion, the more complex the local government, the more weaknesses found in local government control. The results of this study are in line with research Nurwati and Trisnawati (2015). Therefore, provincial governments with large number of districts in 
their area, then the local government will be difficult in implementing internal control. When the complexity of local government is high, internal controls and controls must also be more complex. This happens because the scope of government in conducting supervision and control will become more widespread.

T-test result hypothesis four has a significance value below $5 \%(\alpha=0.05)$ or equal to 0.000 with positive direction at 3.872 coefficient. That is, if there is an increase of 1 human development index, it will have an impact on increase of the internal control weaknesses by 3.872 cases. This means that hypothesis four is rejected because the test results show a positive direction. In conclusion the better the quality of human resources, there will be more weaknesses cases found in local government internal control. This indicates that the better the quality possessed by a person then there is a tendency of the person to abuse its advantages to committing fraud. This cheating can be an act that deviates from the duty that should be met. Therefore, the existing work environment in the government tends to be unhealthy. This has led to the finding of more internal control weaknesses in the local government. The results of this study are not in line with the study Nafidah (2011) but in line with the formulated hypothesis.

Test results for hypothesis five obtained $\mathrm{t}$ value -2.052 with a significance value below $5 \%(\alpha=0.05)$ which is equal to 0.044 and has a negative direction of -14.719 . Thus, every increase of one point of the use of information technology, it will have an impact on the decrease in internal control weakness by 14.719 cases. Hypothesis five is accepted because the test result is significantly negative. This indicates that the more local government use information technology the lesser the weakness of internal control. The results of this finding are not in line with research Yamin and Sutaryo (2015) but in line with the formulated hypothesis.

\section{Conclusion}

This study has demonstrated practices of internal control weaknesses in provincial governments in Indonesia and investigated their determinant factors. There are four variables which are found significant influence toward asset, complexity, quality of human resources and the use of information technology. One variable of economic growth is found not significant influence. Variables which have positive effects are the complexity of local government and quality of human resources. This indicates that the more complex the provincial government and the higher that human development index in the region, the higher internal control weaknesses may occur. This implies that government with complex characteristics and in the area with high human development index should be more aware of internal control weaknesses. This finding does not in line with stewardship theory where the more complex their stakeholders, the lower internal control weaknesses in the organisation. Variables which have negative effects are asset and the use of information technology. This supports accountability theory that local government with greater asset to account for and greater resources in information technology would tend to be more accountable through reduction of internal control weaknesses. In practice, these findings imply that to reduce internal control weaknesses 
in local governments, the local governments need to use more information technology; allocate more resources for improving internal control system, anticipate the increasing complexities of local government, and put emphasis on moral values for human resources.

This study has some limitations. First, it only investigates provincial government for four years report. This means that it has weaknesses in terms of lower external validity. Second, it only used asset as financial variable and economic growth, local government complexities, quality of human resources and the use of information technology as nonfinancial variables. To improve the validity of the research, there is a need to apply this study to the whole city and regent local governments; to include much longer year of observation, eg five years observation; to update date to the latest year; and to add other financial and non financial variables eg. leadership style and amount budget for internal control system development.

\section{References}

Ardi, B. K. (2013). The influence of information technology on the development of accounting information system (in Bahasa: Pengaruh Kemajuan Teknologi Informasi terhadap Perkembangan Sistem Informasi Akuntansi). Jumal Dharma Ekonomi, 20(38).

Asare, T. (2009). Internal Auditing in the Public Sector: Promoting Good Governance and Performance Improvement, International Journal of Government Financial Management, 9(1), 15-29.

Badan Pemeriksa Keuangan Republik Indonesia (Audit Board of the Republic of Indonesia). (2012). Summary of Examination Result Semester 1 year 2012 (in Bahasa: Ikbtisar Hasil Pemeriksaan Semester I Tabun 2012). http://www.bpk.go.id retrieved 6 December 2016.

Badan Pemeriksa Keuangan Republik Indonesia (Audit Board of the Republic of Indonesia). (2013). Summary of Examination Result Semester 1 year 2013 (in Bahasa: Ikbtisar Hasil Pemeriksaan Semester I Tabun 2013). http://www.bpk.go.id retrieved 6 December 2016.

Badan Pemeriksa Keuangan Republik Indonesia (Audit Board of the Republic of Indonesia). (2014). Summary of Examination Result Semester 1 year 2014 (in Bahasa: Ikbtisar Hasil Pemeriksaan Semester I Tahun 2014). http://www.bpk.go.id retrieved 6 December 2016.

Badan Pemeriksa Keuangan Republik Indonesia (Audit Board of the Republic of Indonesia). (2015). Summary of Examination Result Semester 1 year 2015 (in Bahasa: Ikbtisar Hasil Pemeriksaan Semester I Tahun 2015). http://www.bpk.go.id retrieved 6 December 2016.

Badan Pemeriksa Keuangan Republik Indonesia (Audit Board of the Republic of Indonesia). (2016). Summary of Examination Result Semester 1 year 2016 (in Bahasa: Ikbtisar Hasil Pemeriksaan Semester I Tahun 2016). http://www.bpk.go.id retrieved 6 December 2016.

Badan Pusat Statistik Republik Indonesia (Statistics Central Board, Republic of Indonesia). (2016). Human development index (in Bahasa: Indeks Pembangunan Manusia). http://www.bps.go.id retrieved 7 Desember 2016 
Badan Pusat Statistik Republik Indonesia (Statistics Central Board, Republic of Indonesia). (2016). Number of districts (in Bahasa: Jumlab Kecamatan). http://www.bps.go.id retrieved 10 December 2016

Badan Pusat Statistik Republik Indonesia. (Statistics Central Board, Republic of Indonesia) (2016). Economic growth (In Bahasa: Laju Pertumbuhan Ekonomi). http://www.bps.go.id. Retrieved 19 December 2016

Benedek, M., Szenténé, K.T, \& Béres, D. (2014). Internal Controls in Local Governments, Public Finance Quarterly, 3, 296-309.

COSO. (2013). Internal Control- Integrated Network: Executive Summary.

Donaldson, L. \& Davis, J. H. (1991). Stewardship Theory or Agency Theory: CEO Governance and Shareholder Returns. Australian Journal of Management, 16(1), 49-64. https://doi.org/10.1177/031289629101600103

Doyle, J., Ge, W. \& McVay, S. (2007). Determinants of Weakness in Internal Control Over Financial Reporting. Journal of Accounting and Economics, 44(1-2), 193-223. https://doi.org/10.1016/i.jacceco.2006.10.003

Frink, D. D. \& Klimoski, R. J. (2004). Advancing accountability theory and practice: Introduction to the human resource management review special edition. Human Resource Management Review, 14(1), 1-17. https://doi.org/10.1016/i.hrmr.2004.02.001

Hartono, R., Mahmud, A. \& Utaminingsih, N. S. (2014). Factors that influence internal control weaknesses in local government (In Bahasa: Faktor-faktor yang mempengaruhi kelemahan pengendalian internal pemerintah daerah). Simposium Nasional Akuntansi XXVII. 24-27 September 2014. Mataram. Lombok. 1-13.

Kementerian Komunikasi dan Informatika (Ministry of Communication and Information). (2016). PeGI Ranking (In Bahasa: Pemeringkatan PeGI. www.kominfo.go.id retrieved 15 December 2016.

Kristanto, S. B. (2009). The effect of government size, local revenue and capital expenditure predictor of internal control weakness (In Bahasa: Pengaruh ukuran pemerintahan, pendapatan asli daerah (PAD), dan belanja modal sebagai prediktor kelemahan pengendalian internal). Jurnal Akuntansi UKRID A, 9(1). Retrieved from: http://ejournal.ukrida.ac.id/ojs/index.php/Akun/article/view/696

Mardiasmo. (2002). Public Sector Accounting (in Bahasa: Akuntansi sektor publik. Edisi 2). Yogyakarta: Andi Yogyakarta.

Nafidah, L. N. (2011). Implementation of Internal Control System on Avian PT Avia Sidoarjo Viewed From The Quality of Human Resources. Jurnal Entrepreneur, 2(2). Retrieved from: http://www.journal.unipdu.ac.id/index.php/Entrepreneur/article/view/118

Nurwati, I \& Trisnawati, R. (2015). Analysis of factors that affect internal control weaknesses in local government (In Bahasa: Analisis faktor- faktor yang mempengaruhi kelemahan pengendalian internal pemerintah daerah). Syariah Paper Accounting FEB UMS.

Putri, N. K. \& Mahmud, A. (2015). The effect of economic growth, local revenue, size and complexities on local government internal control weaknesses (in Bahasa: Pengaruh pertumbuhan ekonomi, PAD, ukuran dan kompleksitas terhadap kelemahan pengendalian intern Pemda). Accounting Analysis Journal, 4(2). https://doi.org/10.15294/aaj.v4i2.7769

Republik Indonesia. (2004). Act no 1 year 2004 on State Treasury.

Republik Indonesia. (2008). Government Regulation No. 60 year 2008 on Government internal control system.

Rich, K. T \& Zhang J. X. (2014). Does Audit Committee Monitoring Matter in the Government Sector? Evidence from Municipal Internal Control Quality. Journal of 
Governmental \& Nonprofit Accounting, 3(1), 58-80. https://doi.org/10.2308/ogna$\underline{50832}$

Saputro, E. A., \& Mahmud, A. (2015). Analysis of factors that affect local government internal control (In Bahasa: Analisis Faktor-Faktor Yang Berpengaruh Terhadap Kelemahan Pengendalian Intern Pemerintah Daerah). Accounting Analysis Journal, 6(1).

Yamin, R., \& Sutaryo. (2015). Factors that determine the number of findings in internal control weaknesses at Indonesian local government, (In Bahasa: Faktor Penentu Jumlah Temuan Kelemahan Sistem Pengendalian Intern pada Pemerintah Daerah di Indonesia). Simposium Nasional Akuntansi 18 Medan, 119. 